\title{
The Obligation to Volunteer as Fair Reciprocity? Welfare Recipients' Perceptions of Giving Back to Society
}

\author{
Thomas Kampen $^{1}$ (1) $\cdot$ Lex Veldboer $^{2} \cdot$ Reinout Kleinhans $^{3}$
}

Published online: 18 January 2019

(C) The Author(s) 2019

\begin{abstract}
Dutch citizens on welfare have to volunteer at Civil Society Organizations (CSOs) in return for their benefits. Through applying the 'worlds of justification' of Boltanski and Thévenot, this article aims to provide a better theoretical and empirical understanding of social justice of policies that obligate welfare clients to participate in CSOs. The analysis of 51 in-depth interviews with Dutch welfare recipients shows that respondents perceive these policies partly but not unilaterally as unfair. If respondents perceive welfare as 'free money' and if they are convinced that civic behavior demands interventions against free riding on welfare resources, 'mandatory volunteering' is considered as fair. Our main contribution is to the theoretical debate on recognition and redistribution by showing empirically how 'othering' plays an important role in determining when mandatory volunteering becomes a matter of redistribution or recognition.
\end{abstract}

Thomas Kampen

t.kampen@uvh.nl

Lex Veldboer

a.p.m.veldboer@hva.nl

Reinout Kleinhans

r.j.kleinhans@tudelft.nl

1 Department Humanization of the Public Sector, University for Humanistic Studies, Kromme Nieuwegracht 29,

3512 HD Utrecht, The Netherlands

2 Amsterdam Knowledge Centre for Societal Innovation, Amsterdam University of Applied Science, P.O. Box 1025, 1000 BA Amsterdam, The Netherlands

3 Department OTB - Research for the Built Environment, Delft University of Technology, P.O. Box 5043, 2600 GA Delft, The Netherlands
Keywords Social justice - Welfare policies - Workfare · Volunteering $\cdot$ Recognition

\section{Introduction}

The collapse of the Lehman Brothers bank in September 2008 heralded the start of a global financial and economic crisis that rapidly engulfed most of the developed world. A common response has been fiscal and financial austerity on the part of national governments, combined with major reforms and cuts in government spending on welfare, health care, education, infrastructure and housing (Newman and Tonkens 2011). These shifts occur alongside wider trends of welfare state retrenchment (Gilbert 2004). At the same time, governments expect Civil Society Organizations (CSOs) to take on tasks formerly carried out by the public sector, as part of austerity measures.

The wider discourse on the impact of institutional and economic changes involves more than just austerity. It also brings in the long-standing political narrative that welfare systems have undermined civic engagement and solidarity. The former British Prime Minister David Cameron was a clear proponent of this position: "welfare has sent out some incredibly damaging signals: that it pays not to work, that you are owed something for nothing. It has created a culture of entitlement. And it has led to huge resentment amongst those who pay for the system' (quoted in Hoggett et al. 2013, p. 581). Cutting social services and limiting welfare arrangements alongside raising expectations from CSOs are not only framed as 'regrettable but necessary' measures, but also as a good means of activating presumably inactive members of society (see also Verhoeven and Tonkens 2013, p. 415). 
Since 2012, Dutch local authorities are authorized to demand unpaid work at CSOs from welfare recipients. The policy discourse underlying this 'workfare volunteerism' (Kampen et al. 2013) seems to include a strong connection between contemporary ideological views and mundane financial inevitability. Ideologically the policy embodies a vision of maximum (and preferably meaningful) participation in society, either through paid employment or (obliged) volunteering (or both). At the same time, the policy reveals the harsh reality of a local authority that has to implement drastic public budget cuts. This double argument is a continuing element in the discussion. The national government's coalition agreement in 2007 already stated: 'It is socially unacceptable for people to be excluded from society, economically it is unjust' (Balkenende IV 2007).

The obligation to volunteer in the Netherlands is quite unique in the world. The only other countries known to require their unemployed to volunteer in return for benefits are Australia (Warburton and McDonald 2002; Warburton and Smith 2003) and Belgium (De Waele and Hustinx 2018). We should not, however, exaggerate this uniqueness. The Netherlands may be unique, but many countries have similar policies that come close to the idea of mandatory volunteering. In other countries, unemployed people are directed toward the voluntary sector through more informal ways, like being invited by volunteer organizations, as a way of 'activation' (Muehlebach 2012; Lister 2002). Activation of unemployed people is in itself not a new phenomenon. Already in 1998, it was a key element in the European Employment Strategy (Triantafillou 2011, p. 4). What is unique about workfare volunteering though is its primary focus on the public interest instead of putting the interest of the unemployed individual first. The policy that was introduced in 2012 shifts the focus from improving one's individual employability to requiring welfare recipients to volunteer for 'the benefit of society.'

Politicians often frame this quid pro quo approach as 'normal' and 'fair' (Kampen 2014). However, workfare volunteerism is often criticized as 'free labor' (Krinsky 2008) and as part of the 'moral neoliberal' government project of replacing the welfare state with the third sector (Muehlebach 2012), especially in light of austerity. The former criticism is more often heard in liberal welfare state regimes like the USA and the UK, the latter in socialdemocratic or corporatist welfare state regimes, like the ones in continental Europe. Besides from these differences, the two separate criticisms might stem from the different ways volunteering is perceived in both parts of the world; in the Anglo-Saxon context volunteering is often seen as unpaid labor, while in the northern European perspective, including the Netherlands, it is seen as active participation in a community (Dekker 2002).

Among the general public, mutual obligation policies, including mandatory volunteering at CSOs, are increasingly popular (Saunders 2008; Veldheer et al. 2012). The last decade has shown increasing public support for a shift in the balance between rights and responsibilities in social policies (Van der Veen et al. 2012). This growing support is based on the idea that, like the employed, unemployed people ought to do something to earn a living (see also Goodin 2002).

However, while prevailing attitudes among the general public are well known, the views of welfare clients volunteering at CSOs have scarcely been considered in these debates. So far, there is only a very general assumption that those who receive social benefit payments are somewhat less supportive of mandatory reciprocity than the general public as a whole (Van der Veen et al. 2012).

This paper aims to provide a better theoretical and empirical understanding of policies that obligate welfare clients to participate in CSOs. To this purpose, we will explore the extent to which unemployed Dutch citizens view these notions of obligation and reciprocity as fair and how they form their opinions. What is special about our pilot study is that all 51 respondents were already volunteering at CSOs before the introduction of mutual obligation policy in 2012. This was also in their capacity as welfare clients, but not in return for their benefit. Thus, we are not dealing with a random sample of welfare recipients, but with a specific group of people who are experiencing a policy shift from voluntary to mandatory reciprocity, i.e., giving something back to 'society' in return for social security benefits. Some respondents in this group used to receive a small remuneration for their volunteering (on top of the welfare payments), while others were not remunerated. In the first case, people lost their remuneration as part of the policy transition. In our methods section, we will elaborate on the reasons we selected these groups.

This article starts with a closer look at mandatory reciprocity from a theoretical perspective, informed by literature on social justice. Subsequently, we give a brief description of the context of mandatory reciprocity in the Netherlands, our data collection and methods. Based on interview transcriptions, the perceptions of workfare volunteers on the fairness of mandatory volunteering, their activities and valuation processes are analyzed. The paper ends with conclusions and recommendations for further research. 


\section{Debates on Social Justice of Mandatory Volunteering}

Social justice of mandatory volunteering is often debated in terms of redistribution. The main subject of discussion in these debates is conditionality, i.e., the relationship between the right to welfare benefits and personal behavior. This type of debate often comes down to the question 'what should be done about free riders?' (Dworkin 1981). One of the most influential scholars dealing with this topic was Lawrence Mead (1986, 1997). Many contemporary 'work for the dole' programs in Europe, the USA and Australia are based on Mead's ideas.

Inspired by the work of Dworkin, Mead approaches the question in terms of redistribution and argues that welfare benefits ought to be conditional, because it is unfair 'to tax the hardworking for the benefit of those who are equally capable of hard work, and equally talented, but choose to laze around instead' (Wolff 2008, p. 19). For Mead, there should be a balance between the rights and obligations of individuals. He argues that the majority of the worst-off do not act in the interest of the collective unless they are topdown enforced to. He believes that lifestyle changes will improve people's capabilities to improve their life chances. Therefore, he wants to include behavioral requirements for support provided to the worst-off. In his view, demonstrating a work ethic is the key requirement.

However, critics point to the persistent high thresholds to regular work, the denial of the unemployed as former workers and taxpayers, the risk that cheap volunteers could compete with or even displace people with regular jobs, and the potential increase in illegal jobs as a consequence of strategies to avoid having to volunteer (Moss 2006; Nevile and Warwick Nevile 2003; Sawer 2006).

Other scholars, often reacting to Mead's ideas, debate the social justice of mandatory volunteering with regard to recognition instead of redistribution. According to Nancy Fraser, recognition and redistribution should be seen as equally important measurements for social justice; fair policy makes sure that individuals are enabled to 'participate on a par with the rest' (Fraser 2000). In this view, one could say volunteering at CSOs offers welfare clients a way to earn respect for participating on a par with the rest.

However, the turn toward activation has been the subject of much scholarly criticism and debate. Social scientists and philosophers have been very critical of Mead's ideas that unemployment is related to behavioral requirements and lifestyle. Mead's suggestion that disciplining is needed is often depicted as a harsh misrecognition of welfare clients, since they are being withheld from participating on a par with others. It is argued that activation measures, like participants' obligation to do something in return for a welfare benefit, are experienced as 'humiliating and harassing' (Goodin 2002, p. 592), stigmatizing people as having an inferior status by reinforcing notions like 'undeserving poor,' 'welfare queens' or 'welfare fraudsters' (King 1995; Soldatic and Meekosha 2012; Trommel and van de Berg 2012). A common criticism is that the call for activation and more broadly for active citizenship depicts welfare state 'dependency' as 'bad citizenship' (Warburton and Smith 2003), which would deepen stigmatization of welfare clients (Fuller et al. 2008). More specifically, workfare volunteering would depict welfare clients as unable to work under regular labor market conditions and cast as an ever-aspiring, yet permanently failing citizen (De Waele and Hustinx 2018).

Debates on social justice do not tell us much about the actual experiences of justice of those who are subject to workfare volunteerism. For Mead, individual justice would also not be the main goal: 'Programmes to reorganize the lives of the needy by integrating them into mainstream society seek order (for society) rather than justice for individuals' (Mead 1997, p. 11). Empirical research focusing on whether mandatory volunteering is experienced as socially just is difficult to find. Scholars draw conclusions regarding the fairness of mandatory volunteering from their research, but hardly pay attention to how welfare clients experience the fairness of the policy. Our research focuses on the fairness of mandatory volunteering at CSOs from the perspective of those subjected to the policy. Our central question is: how do welfare clients experience the social justice of mandatory volunteering at CSOs and how can we explain their judgments? While answering this question, we will also pay attention to how their perception of their activities changes when this affects their valuation process.

In their book On justification, Boltanski and Thévenot (2006) offer a helpful perspective on the ways people justify something as fair or unfair. They distinguish between six interpretative frameworks by which people assign legitimacy, justification and value to actions (the 'market world,' the 'civic world,' the 'world of fame,' the 'domestic world,' the 'inspired world' and the 'industrial world'). Boltanski and Thévenot's worlds of justification enable us to make sense of workfare volunteers' normative interpretations of mandatory volunteering at CSOs beyond interpreting the policy as fair or unfair from the two dominant positions in the debate on the fairness of the policy so far, because it might help us answering the question why people consider it to be a matter of recognition or redistribution. Before we do so, we will explain the policy shift we are investigating and our methods in the next two sections. 


\section{Policy Background}

When we started our research in 2009, Dutch municipalities were free to choose whether they wanted to oblige, remunerate or otherwise stimulate their welfare clients to volunteer for reasons of individual employability. At the end of our research period in 2013, approximately a fifth of the municipalities in the Netherlands obligated unemployed residents to participate in volunteering with the possibility of a sanction for not complying (Inspectie SZW 2013). The 78 municipalities that had implemented the policy had imposed the measure over 3000 times in the first half of 2013. This is approximately $3 \%$ of the reintegration measures that had been taken in total. ${ }^{1}$

The five research sites were selected from the thirty largest municipalities in the Netherlands. To illuminate the full range of variation, we included three municipalities that remunerated and two that otherwise stimulated volunteering, since these were the two main methods used by different municipalities at that time. We will briefly describe how the local policies on activation of welfare clients differed between our research sites in 2009.

The municipality of Nijmegen offered a premium to stimulate welfare clients to volunteer. The premium was only rewarded under five conditions: (1) only welfare clients who were temporarily relieved from the obligation to apply for jobs qualified for a volunteer premium; (2) a minimum average of $10 \mathrm{~h}$ of volunteering per week. In order to receive the maximum bonus, at least 40 weeks of volunteering per year was required; (3) consent from the case manager; (4) the volunteering had to 'reduce the distance to the labor market'; and (5) the premium was awarded for a maximum period of 24 months.

In Rotterdam, welfare clients could either choose to volunteer in their neighborhood or apply for jobs. When welfare clients started volunteering, they were supported by a 'coach,' either toward maximizing their career as volunteer or to qualify for a regular job via volunteering. Participants had a relatively large free choice in the type of activity and received a maximum remuneration of $€ 63$ a month.

The municipality of Zaanstad provided monthly reimbursements of expenses up to an amount of $€ 95$ to $€ 150$ per month. On top of that, the municipality provided a premium of $€ 250$ per year for welfare clients who did not receive any reimbursement from their CSO and volunteered at least $10 \mathrm{~h}$ per week.

In Eindhoven and Leeuwarden, volunteering was not remunerated. Both municipalities trusted their welfare

\footnotetext{
${ }^{1}$ Information available through: http://www.cbs.nl/NR/rdonlyres/ 6633E417-372B-4B46-A440-8BFEDFA702D2/0/2015srgmaatwerk. xls.
}

officials to stimulate welfare clients to volunteer. Eindhoven's policy was to convince welfare clients that volunteering offers possibilities. The policy of the municipality of Leeuwarden was to seduce their welfare clients to volunteer.

The policy regime that was introduced in 2012 required every citizen to participate in society up to the limits of their capabilities (De Jong 2012). The main idea was that unemployed citizens with a slim chance of finding work on the labor market (due to language deficiencies, their age or the lack of proper education) would be obligated to volunteer for at least $20 \mathrm{~h}$ per week. Rotterdam was one of the first to fully adopt this idea: 'This is necessary for their own employability and to avoid isolation but also to maintain services like elderly care and libraries at an acceptable level,' according to alderman Florijn (Volkskrant 2012). A lot of municipalities hesitated or declined to implement the policy. We did, however, discuss the new policy with our respondents whether they lived in a municipality that was planning on implementing it or not.

The new local policy regime represented three shifts. First, policy has shifted from serving mainly the personal needs to serving mainly a collective interest. The basic idea of the previous policy was to lift the long-term unemployed out of isolation and maximize their labor market prospects. Goals like reinforcing 'civil society,' for instance, were only mentioned as secondary aims. Current policies, however, frame welfare clients' primary responsibility in more general terms, like meeting the needs of the community or contributing to society.

Second, the new regime means a significant shift along the continuum of volunteering (Cnaan et al. 1996). This shift is a move away from a more voluntary approach, with the associated freedom of choice, toward a mandatory approach, with the associated lack of choice. From a study by Handy et al. (2000), we know that in people's perceptions a shift in context toward more restrictions on the freedom of choice to volunteer and a more obligatory character result in a move away from a person being perceived as a volunteer (Handy et al. 2000). Our study will show how this shift affects volunteers' perception. This is important, since normative pressures to volunteer are increasing as a reaction to disembeddedness of volunteering (Hustinx and Meijs 2011). And this third sector involvement is not limited to governments, but also applied by corporations and educational institutions with different gradations of pressure or coercion (Haski-Leventhal et al. 2010; Hustinx and Meijs 2011).

Third, there has also been a shift from additional remuneration to financial penalties. This might cause a shift in the opposite direction, according to the net cost approach by Handy et al. (2000), who have shown that less rewards result in a shift in perception toward volunteerism. 
In other words, ending remuneration will increase the net costs of volunteering, making the activities more likely to be perceived as volunteering (Handy et al. 2000). This is especially true for the Dutch case, since in the Netherlands individuals receiving any paid remuneration are less likely to be considered a volunteer compared to other countries (Meijs et al. 2003).

\section{Data and Methods}

Our research population consists of unemployed people in the aforementioned five municipalities who were volunteering at a CSO and were faced by new policies on mandatory volunteering. We selected this particular group because it allowed us to research how the shifts that characterize the new policy regime (ending remuneration, from voluntary to mandatory participation and from personal to collective interest) are experienced. Of course, this selection also comes with disadvantages, since our selection contains only people that were interested in volunteering in the first place. This does not allow us to generalize our findings to other welfare clients. However, selecting only welfare clients who were already engaged in volunteering does enable us to investigate how they judge the actual policy changes.

Local government officials working on activation policies mediated between the researchers and potential respondents. We drew a sample of research informants from the welfare databases of the participating municipalities. Because we wanted to explore different opinions on social justice, we sought to include in our sample a maximum spread in age, years of unemployment, gender, and ethnicity, and in type of volunteer sector (neighborhood; cultural; educational; advocacy; care). Considering our financial resources, we approached 177 people distributed over five cities. Of these 177, 24 did not answer the phone or responded to the invitation letter; 102 people responded but refused to participate. This is a relatively high non-response rate, which may reflect issues of selection bias. For instance, the 'refusers' may be people who want to keep their view on welfare and policy changes to themselves and therefore did not take part. Therefore, we asked for reasons for non-response, with the main answers being a lack of interest or research fatigue. Ultimately, we conducted 51 in-depth interviews. The interviews took place between 2009 and 2013. Many of the respondents reported physical or psychosocial problems, and many had been volunteering for several years (see Table 1). The initial volunteering was mostly a way to deal with a change in the life story (divorce, children leaving the parental home, partner passed away, etc.).
We used a semi-structured instrument based on openended questions. These questions covered topics relating to respondents' personal biography, past experiences with volunteering, current volunteering activities and ideas about mandatory volunteering. The interviews were conducted in respondents' homes and lasted between $30 \mathrm{~min}$ and $2 \mathrm{~h}$. All the interviews were digitally recorded, transcribed (verbatim) and analyzed with the qualitative data software ATLAS.ti. First we carried out a grounded theory analysis using an inductive approach to identify judgments of the fairness of the new policy by our informants. In this first step, we coded every sentence in the transcription that revealed a judgment or normative statement on the respondent's situation and individual arrangement of his/ her volunteering activities. We paid particular attention to words reflecting a strong message, such as 'fair,' 'unfair,' 'must,' 'should,' 'earn,' 'deserve,' 'employment,' 'society,' and 'in return'/'in exchange.' Subsequently, we considered Charles Tilly's (2008) work on reasoning justification and Boltanski and Thévenot's work on worlds of justification. After we determined that the arguments put forward by our informants would best be analyzed through the lens of Boltanski and Thévenot's worlds of justification, we used a more deductive Critical Discourse Analysis to make sense of underlying ideologies regarding the judgments of our informants. The basic assumption underlying discourse analysis is that language shapes our view of the world and is not neutral or simply mirroring reality (Hajer 2006). Discourse analysis is a useful approach to understand how particular ideas are privileged as 'truth.' For each of the worlds of Boltanski and Thévenot, we constructed a short theoretical proposition (discussed in each of the subsections in the results part of the paper). We manually allocated every coded normative statement or judgment to one of the worlds (while retaining the respondent number with the code). When multiple judgments were made in one interview, we have attributed these respondents to the world that emerged most prominently in their argumentation. In cases of doubt, the researchers discussed the allocation and completed the coding based on mutual agreement. Below we present our key empirical findings on social justice by using Boltanski and Thévenot's work. In order to safeguard their anonymity, the names of the respondents are fictitious.

Because we focus on one country (and a small number of municipalities), the external validity of our findings is limited. However, our transcript analysis does not imply any claim of 'authenticity' of 'verificational realism' (Crang 2002), but enables us to unearth common and different experiences among the interview respondents. This is in line with our aim to provide our theoretical and empirical understanding of social justice of policies that obligate welfare clients to participate in CSOs. 
Table 1 Personal characteristics of the interviewees

\begin{tabular}{|c|c|c|c|c|c|c|c|}
\hline Respondent & Sex & Age & $\begin{array}{l}\text { Years of } \\
\text { unemployment }\end{array}$ & $\begin{array}{l}\text { Highest educational } \\
\text { attainment }\end{array}$ & $\begin{array}{l}\text { Ethnic } \\
\text { background }\end{array}$ & Health situation & $\begin{array}{l}\text { World of } \\
\text { justification }\end{array}$ \\
\hline $\mathrm{R} 1$ & $\mathrm{~F}$ & 53 & $>10$ & Primary school & Hindustani & Chronic physical pain & Inspired world \\
\hline $\mathrm{R} 2$ & $\mathrm{~F}$ & 62 & $>10$ & $\begin{array}{l}\text { Advanced elementary } \\
\text { education* }\end{array}$ & Dutch & Chronic physical pain & Civic world \\
\hline R3 & $\mathrm{F}$ & 58 & $>10$ & Primary school & Surinamese & Physical complaints & $\begin{array}{l}\text { Market (no free } \\
\text { labor) }\end{array}$ \\
\hline $\mathrm{R} 4$ & $\mathrm{~F}$ & 56 & $>10$ & Primary school & Surinamese & No problems & $\begin{array}{l}\text { Market (no free } \\
\text { money) }\end{array}$ \\
\hline R5 & $\mathrm{F}$ & 55 & 10 & $\begin{array}{l}\text { Advanced primary } \\
\text { education }\end{array}$ & Surinamese & Chronic physical pain & Civic world \\
\hline R6 & $\mathrm{F}$ & 56 & $>10$ & $\begin{array}{l}\text { Lower general secondary } \\
\text { education* }\end{array}$ & Dutch & Chronic physical pain & $\begin{array}{l}\text { Market (no free } \\
\text { labor) }\end{array}$ \\
\hline $\mathrm{R} 7$ & $\mathrm{~F}$ & 61 & $>10$ & $\begin{array}{l}\text { School for domestic } \\
\text { science* }\end{array}$ & Dutch & $\begin{array}{l}\text { Physical complaints and } \\
\text { psychological problems }\end{array}$ & Civic world \\
\hline $\mathrm{R} 8$ & $\mathrm{~F}$ & 50 & 5 & Primary school & Turkey & Physical complaints & Inspired world \\
\hline R9 & $\mathrm{F}$ & 57 & $>10$ & $\begin{array}{l}\text { School for domestic } \\
\text { science* }\end{array}$ & Dutch & Physical complaints & $\begin{array}{l}\text { Market (no free } \\
\text { money) }\end{array}$ \\
\hline $\mathrm{R} 10$ & $\mathrm{~F}$ & 29 & 4 & Secondary school & Iraq & No problems & Inspired world \\
\hline $\mathrm{R} 11$ & M & 48 & $>10$ & $\begin{array}{l}\text { Advanced primary } \\
\text { education }\end{array}$ & Surinamese & No problems & $\begin{array}{l}\text { Market (no free } \\
\text { labor) }\end{array}$ \\
\hline $\mathrm{R} 12$ & M & 50 & $>10$ & Secondary school & Dutch & Psychiatric complaints & World of fame \\
\hline $\mathrm{R} 13$ & M & 56 & 10 & Primary school & Dutch & No problems & World of fame \\
\hline $\mathrm{R} 14$ & $\mathrm{~F}$ & 45 & 8 & Higher education & Dutch & Mental problems & Inspired world \\
\hline $\mathrm{R} 15$ & $\mathrm{~F}$ & 42 & 5 & $\begin{array}{l}\text { Advanced primary } \\
\text { education }\end{array}$ & Dutch & $\begin{array}{l}\text { Physical complaints and } \\
\text { psychological problems }\end{array}$ & Domestic world \\
\hline $\mathrm{R} 16$ & M & 44 & 7 & Primary school & Dutch & Physical complaints & Inspired world \\
\hline $\mathrm{R} 17$ & $\mathrm{~F}$ & 29 & 5 & $\begin{array}{l}\text { Advanced secondary } \\
\text { education }\end{array}$ & Turkish & Psychological problems & Civic world \\
\hline $\mathrm{R} 18$ & M & 46 & $>10$ & Primary school & Dutch & Psychosocial problems & Domestic world \\
\hline R19 & M & 60 & $>10$ & Primary school & Dutch & Physical complaints & Inspired world \\
\hline $\mathrm{R} 20$ & $\mathrm{~F}$ & 57 & 7 & $\begin{array}{l}\text { Advanced secondary } \\
\text { education }\end{array}$ & Dutch & Chronic physical pain & World of fame \\
\hline $\mathrm{R} 21$ & $\mathrm{~F}$ & 54 & 4 & Primary school & Dutch & Chronic physical pain & Civic world \\
\hline $\mathrm{R} 22$ & M & 34 & 6 & $\begin{array}{l}\text { Advanced primary } \\
\text { education }\end{array}$ & Turkish & No problems & Inspired world \\
\hline $\mathrm{R} 23$ & $\mathrm{~F}$ & 45 & 8 & $\begin{array}{l}\text { Lower general secondary } \\
\text { education* }\end{array}$ & Dominican & $\begin{array}{l}\text { Physical complaints and } \\
\text { psychological problems }\end{array}$ & Civic world \\
\hline $\mathrm{R} 24$ & M & 47 & 4 & Higher education & Dutch & Chronic physical pain & Inspired world \\
\hline $\mathrm{R} 25$ & M & 51 & 5 & Primary school & Dutch & Chronic physical pain & Civic world \\
\hline $\mathrm{R} 26$ & M & 32 & $>10$ & $\begin{array}{l}\text { Advanced elementary } \\
\text { education* }\end{array}$ & Dutch & No problems & $\begin{array}{l}\text { Market (no free } \\
\text { labor) }\end{array}$ \\
\hline $\mathrm{R} 27$ & M & 55 & $>10$ & Primary school & Dutch & Physical complaints & Inspired world \\
\hline $\mathrm{R} 28$ & $\mathrm{~F}$ & 44 & 9 & Primary school & Romanian & Physical complaints & Domestic world \\
\hline $\mathrm{R} 29$ & $\mathrm{~F}$ & 61 & $>10$ & $\begin{array}{l}\text { Advanced elementary } \\
\text { education* }\end{array}$ & Dutch & No problems & $\begin{array}{l}\text { Market (no free } \\
\text { money) }\end{array}$ \\
\hline $\mathrm{R} 30$ & M & 28 & 4 & $\begin{array}{l}\text { Advanced secondary } \\
\text { education }\end{array}$ & Dutch & Psychiatric complaints & Domestic world \\
\hline $\mathrm{R} 31$ & $\mathrm{~F}$ & 43 & $>10$ & Primary school & Dutch & No problems & Domestic world \\
\hline $\mathrm{R} 32$ & $\mathrm{~F}$ & 50 & 10 & $\begin{array}{l}\text { Advanced primary } \\
\text { education }\end{array}$ & Dutch & Mental problems & Inspired world \\
\hline $\mathrm{R} 33$ & $\mathrm{~F}$ & 51 & 5 & $\begin{array}{l}\text { School for domestic } \\
\text { science* }\end{array}$ & Dutch & $\begin{array}{l}\text { Physical complaints and } \\
\text { psychological problems }\end{array}$ & Inspired world \\
\hline R34 & M & 46 & 7 & Primary school & Moroccan & Physical complaints & Civic world \\
\hline
\end{tabular}


Table 1 continued

\begin{tabular}{|c|c|c|c|c|c|c|c|}
\hline Respondent & Sex & Age & $\begin{array}{l}\text { Years of } \\
\text { unemployment }\end{array}$ & $\begin{array}{l}\text { Highest educational } \\
\text { attainment }\end{array}$ & $\begin{array}{l}\text { Ethnic } \\
\text { background }\end{array}$ & Health situation & $\begin{array}{l}\text { World of } \\
\text { justification }\end{array}$ \\
\hline $\mathrm{R} 35$ & M & 44 & $>10$ & Primary school & Dutch & Psychological problems & $\begin{array}{l}\text { Market (no free } \\
\text { labor) }\end{array}$ \\
\hline $\mathrm{R} 36$ & $\mathrm{~F}$ & 58 & 8 & Primary school & Moroccan & No problems & Civic world \\
\hline R37 & M & 39 & 6 & Higher education & Dutch & No problems & Inspired world \\
\hline R38 & M & 41 & 9 & $\begin{array}{l}\text { Advanced primary } \\
\text { education }\end{array}$ & Chinese & Psychosocial problems & $\begin{array}{l}\text { Market (no free } \\
\text { money) }\end{array}$ \\
\hline R39 & $\mathrm{F}$ & 33 & 4 & Primary school & Polish & Psychosocial problems & Domestic world \\
\hline $\mathrm{R} 40$ & M & 49 & $>10$ & Primary school & Dutch & Psychiatric complaints & $\begin{array}{l}\text { Market (no free } \\
\text { money) }\end{array}$ \\
\hline R41 & M & 49 & 7 & Secondary school & Dutch & No problems & Civic world \\
\hline $\mathrm{R} 42$ & $\mathrm{~F}$ & 56 & $>10$ & $\begin{array}{l}\text { Advanced primary } \\
\text { education }\end{array}$ & Dutch & Mental problems & World of fame \\
\hline $\mathrm{R} 43$ & M & 31 & 3 & Secondary school & Dutch & $\begin{array}{l}\text { Physical complaints and } \\
\text { psychological problems }\end{array}$ & Civic world \\
\hline $\mathrm{R} 44$ & M & 39 & 4 & $\begin{array}{l}\text { Advanced primary } \\
\text { education }\end{array}$ & Iranian & Physical complaints & Domestic world \\
\hline $\mathrm{R} 45$ & M & 47 & 5 & $\begin{array}{l}\text { Lower general secondary } \\
\text { education* }\end{array}$ & Dutch & Physical complaints & Civic world \\
\hline $\mathrm{R} 46$ & M & 46 & $>10$ & $\begin{array}{l}\text { Lower general secondary } \\
\text { education* }\end{array}$ & Dutch & No problems & Inspired world \\
\hline $\mathrm{R} 47$ & $\mathrm{~F}$ & 59 & $>10$ & Primary school & Moroccan & Psychiatric complaints & Civic world \\
\hline $\mathrm{R} 48$ & $\mathrm{~F}$ & 49 & 10 & Primary school & Dutch & Physical complaints & Domestic world \\
\hline $\mathrm{R} 49$ & M & 37 & 4 & Higher education & Dutch & $\begin{array}{l}\text { Physical complaints and } \\
\text { psychological problems }\end{array}$ & World of fame \\
\hline $\mathrm{R} 50$ & $\mathrm{~F}$ & 40 & $>10$ & Primary school & Dutch & Physical complaints & Domestic world \\
\hline R51 & M & 54 & 6 & Secondary school & Dutch & Psychological problems & Inspired world \\
\hline
\end{tabular}

*These are forms of primary and secondary education that have already disappeared in The Netherlands, as a result of educational reforms

\section{Six Ways to Evaluate Mandatory Volunteering}

In general, most of the respondents judge the policy measure as unfair. Still, 18 out of 51 respondents judge the measure as fair. In this section of the article, we use Boltanski and Thévenot's worlds of justification to shed more light on the ways in which workfare volunteers judge the obligation to volunteer, and the reasons why they judge it that way. Our analysis will answer the question to what extent the shift from the former policy context (characterized by personal interest, voluntariness, and possible remuneration) to the current policy context (characterized by collective interest, obligation, and possible penalties) is perceived as fair or unfair by workfare volunteers' and we will explain their judgments. Each subsection below starts with a short description of the respective world of justification, followed by analysis of the valuation process regarding fairness of the policy and changing perception of volunteer activities illustrated by relevant excerpts from the interview transcriptions.

\section{Market World: No Free Money}

According to Boltanski and Thévenot (2006), money is the measure of all things in the 'market world.' The desire of people to possess and deserve scarce supplies through money is the driving force behind their actions. People enter into relationships of exchange and transactions. In the market world, the price of something or someone's efforts is a proof of value, and this value is expressed in money. In other words, matters of material redistribution (and conditions for this) are on the forefront.

Out of 51 respondents, five of them view mandatory volunteering straightforwardly from this 'market world perspective' (see Table 2). Just as the general public, they argue that nothing comes for free and that a shift from voluntary to mandatory CSO participation is reasonable. 
Table 2 Worlds of justification

\begin{tabular}{lc}
\hline World of justification & Number of respondents \\
\hline Market world (no free money) & 5 \\
Market world (no free labor) & 5 \\
Civic world & 13 \\
World of fame & 5 \\
Domestic world & 9 \\
Inspired world & 14
\end{tabular}

These workfare volunteers consider a welfare benefit without a mutual obligation between benefit provider and recipient as 'free money,' so doing something in return makes redistribution policies fair in this perspective. Janet (56) explains:

At home I was taught that you have to work for your money. I do not see my allowance as a hand-out, but as a salary. Now they are saying: anyone who receives a welfare benefit should do some volunteer work in return. I think that is only fair. (female, 56 years, unemployed for over ten years)

Since this category of workfare volunteers perceives social justice in terms of redistribution, 'getting free money' is especially perceived as unfair for the 'taxpayer,' i.e., those who perform work for a salary. Interestingly, their valuation of their activities legitimizes volunteering in a very specific way. Having to volunteer makes them see their benefit as a 'salary,' which also enables them to perceive their volunteer activities as 'work.'

This category of respondents is critical of other welfare clients who are not arguing in line with their quid pro quo reasoning: 'I was brought up to believe that you don't get something for nothing in life, but others apparently think quite differently sometimes. They just say, I'm not leaving the house for that, you know' (male, 57 years, unemployed for over 10 years).

Reasoning that volunteering is a legitimate demand because in the market world nothing comes for nothing, is in line with the arguments of Mead and Dworkin, for whom the work ethic is a central pillar of their conception of redistributive social justice.

\section{Market World: No Free Labor}

Judging from the same 'market world perspective', another five respondents (different people from the respondents mentioned in the previous subsection) came to a seemingly opposite conclusion about mandatory volunteering policies. In a market world, competing with each other in a fair way is worthy behavior (Boltanski and Thévenot 2006).
People compete for profit, positions, and goods, earning their money in an honest way. However, it is regarded unfair (for workers and for competitors) when (public) entrepreneurs force their workers to deliver public or commercial goods without a material reward.

Workfare volunteers judging the new policy from this side of the 'market world perspective' perceive social justice in terms of the maldistribution of labor. They conclude that it is unfair, since they have to do unpaid work that is likely to replace the work of current paid employees (often in the public sector) whose job may be under threat by austerity regimes and budget cuts. While these respondents are already hesitantly doing unpaid work at a CSO, the shift from a focus on individual employability to a collective interest is seen as a catalyst of 'unfair competition' with low-paid and low-skilled workers. This lack of attention for the material interest of themselves and other economic vulnerable groups disturbs them. Especially middle-aged workfare volunteers judge the new policy this way. Freddy (48) judges ignoring his material interests in the new policy regime as 'slavery' and feels 'stupid' complying:

At some point, in all those retirement homes you will find only volunteers; they get rid of paid staff and the volunteers start marching in. I'm a small fish, and this is how they keep the small fish stupid. In a way I'm supporting the big fish, because management is not cutting back on their own salary, are they? If you really need a volunteer why not employ someone? Obviously, you need workers. (male, 48 years, unemployed for over ten years)

Janet (56) also points to the unfair competition between unpaid and paid workers: 'But the danger then is, of course, that you will get a lot of volunteers who are doing work that really ought to be paid work, and they are going to be in competition with paid staff' (female, 56 years, unemployed for over 10 years). These judgments show that from their perspective the new policy devalues their own volunteering, since now they are no longer valued as volunteers but a threat to paid staff.

In sum, from a market world perspective workfare volunteers can judge obligation either as very fair or as very unfair. But why do workfare volunteers who judge the policy measure from a market world perspective come to such contradictory conclusions? In the market world, redistribution is central, but an important question for workfare volunteers seems to be 'redistribution of what?'. The difference between perceiving the situation as receiving 'free money' or as doing 'free labor' is determined by how they perceive social justice: as redistribution of money or redistribution of labor. Both perceptions call to mind a different 'other.' Those who see the 'taxpayer' as 
most relevant other, judge the obligation to volunteer as fair, while those who see 'low-paid, low-skilled workers' as most relevant reject this policy as unfair.

\section{Civic World: Recognition of One's Contribution to Society}

Among 13 of the 51 respondents, the policy shift toward mandatory volunteering triggers a 'civic world perspective.' The civic world ascribes more value to the community than to the individual, i.e., the collective interest transcends the interests of the individuals that comprise it (Boltanski and Thévenot 2006). A community consists of peers who jointly and unselfishly strive for a collective purpose. The more general the purpose, the greater value the civic world ascribes to it. Whoever contributes to the efforts to achieve unity increases in value in the civic world, in which social equality is a core value.

Respondents approaching the expiration of voluntariness from this 'civic world perspective' formulate the most positive response to the policy shift, by judging that their activities at the CSO are increasingly recognized as relevant for the public interest (see also Fraser 2000). The shift enables them to increase the value of their activities by aligning them with paid work; they told us their activities are different, but just as meaningful as paid work or even more important. For example, Elif (29), a Turkish-Dutch woman, who volunteers at a horse riding school for mentally disabled children, values her activities as something that 'really matters' and 'something more real than a desk job' (female, 29 years, unemployed for 5 years).

They also agree with moving away from voluntariness toward a more obliging character of activating welfare policies. From a civic world perspective, freedom is of great importance, but social unity and social contributions are held in even higher regard (Boltanski and Thévenot 2006, p. 187). Hence, obligation is legitimized on the grounds of taking part in a collective effort for the benefit of 'society.' Again, it matters who they have in mind as 'the other.' In many cases, these 'others' are other welfare clients, who are accused of not contributing to society. Respondents applying a civic world perspective consider the policy transition as fair, because other welfare clients who are supposed to 'lack a certain mentality' can no longer avoid their responsibility for contributing to a public interest. At the same time, the new policy is considered fair by this category of respondents, by recognizing their own contribution in the present and past.

For young people, I do think it's okay [this mandatory volunteering]. After all it's easier for them. And they still have a completely different... mentality in that area, as far as work is concerned. I think it's okay to make them do something. For older people I think you have to look at the individual circumstances. (female, 62 years, unemployed for over ten years)

This narrative joins seamlessly with the findings of a recent study on responsibility (Veldheer et al. 2012), which shows that the majority of Dutch citizens agrees with the principle of personal responsibility, but that most people also believe they already take enough responsibility for themselves and that it is mainly other people who fall short (i.e., those who are supposed to fall back on benefits all too easily) to contribute to society. In our sample, we found this line of reasoning especially among respondents of 45 years of age or older. From a civic world perspective, the mandatory volunteering policy framework with a focus on them as a responsible asset for the collective feels fair to them. The reason for their judgment is that it supports their belief that everyone needs to contribute to society, so 'others' are no longer allowed to withdraw from their responsibility. Not because everyone needs to contribute to society as a way of redistributing responsibilities (they themselves do not want to do less, for instance), but because contributing to society offers people indispensable recognition. Older workfare volunteers seem to experience the policy shift toward a more obliging framework with a focus on the collective interest as recognition for their own contribution and it triggers an image of the non-contributing 'other,' mostly youngsters, for whom more obligation is necessary.

\section{World of Fame: Misrecognition of One's Status}

Another five respondents consider the policy transformation from a 'world of fame' perspective. In the world of fame, a person feels valued by the extent to which others value them (Boltanski and Thévenot 2006). People are sensitive to the opinion of others, or the public opinion in the world of fame. Status is important and is confirmed by praise and compliments from others. Visibility is an important condition for getting attention, encouragement and hence appreciation.

Respondents applying this 'world of fame perspective' argue that the obligation to fulfill mostly low-valued societal demands (by volunteering at a CSO) is unfair, since it affects how they are valued by relevant others. These respondents perceive the shift toward a more obligating framework as unfair if it decreases their freedom of choice for a suitable activity with the appropriate intellectual level. When this condition regarding freedom of choice is not met, workfare volunteers consider obligation as a denial of their status and as an obstacle to be proud of their achievements. For example, Theo has been volunteering as an art teacher at a community center for people 
with psychiatric disorders. He sees the obligation as a possible restriction of his freedom to teach a certain level: 'I'm fine with giving an etching workshop, but only to people who are already familiar with the technique. I' $m$ not going to do beginners, (...) because they have neither the skills nor the intelligence' (male, 50 years, unemployed for over 10 years). So, informants judging the obligation from a 'world of fame perspective' consider the obligation to volunteer as a threat to their status, since it might force them to take on inferior tasks. This threat changes their idea of the way people view their activities.

The same holds for ending remuneration under the new policy framework. All workfare volunteers we spoke to worry a lot about marginalization and oblivion. Respondents applying the 'world of fame perspective' often consider remuneration as a safeguard against marginalization, because they experience a premium as 'a token of recognition and appreciation' (male, 56 years, unemployed for 10 years). Hence, ending remuneration risks ending appreciation. Oblivion and marginalization are being feared in the world of fame. Banality and indifference of others affect a person's dignity (Boltanski and Thévenot 2006, pp. 184-185).

The importance of recognition is in line with the work of Fraser (2000), but there is also a material side to it. Remuneration in the form of money offers workfare volunteers the opportunity to improve their status and appearances. Therefore, cutting a remuneration for volunteering is especially considered as unfair since it increases the risk of being looked down upon by relevant others. Even though financial remuneration does not appear as high in absolute terms, workfare volunteers expect that cutting payments will undermine their status. Especially among middle-aged women, the ending of remuneration and the threat of possible penalties are perceived as unfair and as misrecognition of how they value their appearance: 'Because you are going to work somewhere, you don't want to go looking scruffy. We already don't have much money to spare and now we don't have this little bit extra either' (female, 56 years, unemployed for over 10 years).

Just like respondents using the 'civic world perspective,' those respondents applying a 'world of fame perspective' are strongly concerned about fairness toward themselves. However, the difference is that the former perspective is mostly represented by respondents perceiving rewards and feeling valued, while 'the world of fame' perspective mostly represents people who experience misrecognition in terms of their freedom of choice, status and appearances. The reason that they perceive the policy measure so differently is that the latter have a different 'other' in mind than the people judging the measure from a civic world perspective: people they come across in daily life, instead of other people on welfare that do not contribute.

\section{Domestic World: Misrecognition of Care Tasks}

In the domestic world, one's value depends on one's position in the community (Boltanski and Thévenot 2006, p. 164). The domestic world focuses on the interdependence and loyalty in domestic and familial relationships. It is characterized by hierarchical inequality and in that sense it is different from the civic world in which equality is a core value. The value of the position that a person occupies within the hierarchy is determined by relationships with others who appreciate him or her. Qualities that are valued are discretion, loyalty, punctuality and hospitality (Boltanski and Thévenot 2006, p. 166). Again in contrast to the civic world, dependence within a community is important in the domestic world. This dependence is not something that someone needs to be ashamed of. The family circle may be limited to family, but may also include other relatives, such as friends, neighbors or the local community a whole.

The nine (out of 51) respondents approaching mandatory volunteering from a 'domestic world perspective' experience it as highly unfair. Their loss of 'income' by the termination of previous remuneration for volunteering is experienced as misrecognition of their responsibility to care for their family. In light of this sometimes very demanding responsibility, any requirement to volunteer in return for welfare benefits (without additional remuneration) is considered as a very unjust claim on their precious time (cf. Fuller et al. 2008). A typical example is Inge (42), who has been working at a home care facility on a voluntary basis while experiencing a lot of stress because of the care for her autistic son and suicidal daughter. Now that remuneration for her volunteering has ended, she feels that her priorities lie with her children. However, the risk of being penalized (by diminishing welfare benefit payments) is still there. She explains:

Look, I feel like all welfare clients' situations are just lumped together. That's not right. I know there are more people like me, for whom the situation at home hardly allows them volunteer. Some people experience more stress than others. The law does not take this into account. (female, 42 years, unemployed for five to ten years)

Ending remuneration sharply reduces the value of volunteering for those who judge the new situation from a 'domestic world perspective.' While before they were able to value volunteering as a way to provide for their children, ending remuneration makes them view volunteering as a distraction from caring for their children. The reason for judging the policy measure as a form of misrecognition instead of maldistribution is again 'the other' our informants have in mind. To those who are judging the situation 
from a 'domestic world perspective,' the meaningful 'others' are their children or other family members who are their first priority. Our informants do not believe their care responsibilities should, for instance, be more equally distributed; they feel society misrecognizes the importance of their care responsibilities. A policy transition to mandatory volunteering is very likely to erode the fulfillment of this priority and is therefore considered as unfair (see also Brady 2011). When thinking about other people on welfare benefits, Inge thinks that there are some people that 'should certainly be convinced to do volunteer work,' but she feels the situation at home and the strength of that particular person should be decisive in that matter.

\section{Inspired World: Misrecognition of Passion}

Number five in the six worlds of justification of Boltanski and Thévenot is the 'inspired world.' This world ascribes value to inspiration (Boltanski and Thévenot 2006, p. 159). Value is attributed to individuals who strive for perfection through inspiration and happiness. In the inspired world, value manifests itself as a feeling or passion, which spontaneously comes from within. The 'inspired actions' are motivated by an intrinsic desire to create, and certainly not by money.

A relatively large share of our respondents $(n=14)$ adopts an 'inspired world perspective.' Regardless of policy, their most important reason to volunteer at a CSO is to have the opportunity to engage with something that moves them. The direct opposite of their idea of inspiration would be to do something they consider as mind-numbing. Workfare volunteers in this response category especially disagree with the shift to obligation. Obligation evokes associations with obstinacy and therefore conflicts with their image of volunteering as a passion and a road to inspiration. These associations evoke a fear that their wishes and ambitions will be neglected in volunteering when imposed by welfare benefit suppliers. Obligation is considered as being counter-productive, because being required to do something against their will, is going to make them unhappy.

People should be given the chance to do something that is in their nature, so to speak. Not something that doesn't interest them. It would be illogical to oblige me to volunteer as a captain on a ship, while that doesn't suit me at all. Even though I am a big fan of Popeye [laughs]. (male, 44 years, unemployed for five to ten years)

Unlike in the 'world of fame' perspective, in the 'inspired world perspective' the judgment of others is inferior to listening to your 'inner self.' People should not be afraid of the pain that goes with condemnation by others.
Uncertainties are appreciated and therefore the 'inspired' are looking to take the risk of being judged (Boltanski and Thévenot 2006).

The obligation also affects workfare volunteers' perception of their volunteer activities. Before the policy transition, these workfare volunteers ranked the activities as second best behind inspiring jobs. They are afraid that under the new policy, mandatory volunteering (up to $20 \mathrm{~h}$ per week) becomes a hindrance to find paid employment that really excites them. Obliged volunteering feels like being forced in the wrong direction, especially because previous efforts to improve individual employability have been discarded in the new policy:

I would rather have them investing in me by training me for a teaching job, than making me do volunteer work. If I was trained, I wouldn't need to ask for help any more. Now all I can hope for is a job at Blokker or Hema [warehouse retailers], if they think I'm not qualified enough. (female, 29 years, unemployed for one to five years)

We found this emphasis on limited advantages of volunteering for one's labor market opportunities, especially among younger workfare volunteers. Older respondents were far less outspoken on this matter and seemed to anticipate a prolonged workfare volunteer 'career,' since they are convinced that their chances to re-enter the labor market are very low.

The reason for judging the policy measure as unfair is not a matter of redistribution, but a matter of misrecognition. The policy measures invoke them to imagine another 'self' that is obligated to do something he or she does not want to. They are not afraid of the judgment of others, but they are afraid to misrecognize their own 'true' self.

\section{Conclusions}

In many Western countries, policymakers and the general public are increasingly supportive toward mutual obligation policies. A key reason behind the support for 'mandatory volunteering' is that it is considered as a matter of fair reciprocity. Also in the Netherlands, public opinion is increasingly favoring conditional welfare payments (Van der Veen et al. 2012; Veldheer et al. 2012). While the views of the general public, scholars and policymakers are well recorded, we know little about the perceptions of the subjects of this type of quid pro quo welfare policy regarding its fairness.

There are indications that welfare recipients consider such policies as unfair, penalizing, humiliating, and 'blaming the victim' (King 1995; Goodin 2002; Soldatic and Meekosha 2012). However, empirical studies are 
scarce. This paper addresses this empirical gap by offering a better understanding of social justice of policies that obligate welfare clients to participate in Civil Society Organizations (CSOs). Using the work of Fraser (2000) on recognition and redistribution, and Boltanski and Thévenot's (2006) 'worlds of justification,' we revealed how welfare clients perceive the shift from a voluntary to a mandatory approach. The adoption of Boltanski and Thévenot's 'worlds of justification' sheds a new light on why welfare clients judge mandatory volunteering as fair or unfair, but also on when and why it becomes a matter of redistribution or a matter of recognition.

The results show that interview respondents adopt different perspectives, that fit with the conceptualization of five of the six worlds of justification of Boltanski and Thévenot: the market world, the civic world, the world of fame, the domestic world, and the inspired world. The 'industrial world,' the sixth world of Boltanski and Thévenot, is the only world that did not explicitly resonate in the judgments of our respondents. The industrial world has a continuing focus on progress, targets, standardization, trajectories and control. The policy shift can, however, be seen as a move toward these industrial world values, since obligation implies control by welfare benefit providers and restricting choice combined with less focus on the personal interest of welfare recipients implies more standardization. As a result, the industrial world is present as a counternarrative in the judgments of workfare volunteers. Standardization, for instance, is implicitly judged as unfair from an inspired as well as a domestic world perspective.

Not surprisingly, from the lens of most worlds, the policy is viewed as unfair. However, using the lens of these worlds of justification, we found that several respondents conclude that mandatory volunteering is actually fair and socially just. If respondents framed welfare benefits as 'free money' without an obligation to do something in return (market world), and/or if they were convinced that civic behavior requires measures against free riding and avoiding responsibility (civic world), mandatory volunteering was seen as fair. Among other respondents the obligation actually raised the value of volunteering, since they claimed that their volunteering is now increasingly recognized as a contribution to the public interest (civic world). They legitimize the obligation of volunteering on the grounds of taking part in a collective effort for the benefit of 'society.' Many of our respondents, mostly the older ones, accept the obligations and thereby seem to show a high work ethic and a high level of responsibility toward society. This contradicts with Lawrence Mead's claim that welfare clients lack the work ethic that he believes justifies making welfare conditional.

Respondents' reasons to label mandatory volunteering as unfair are manifold. First, they feel that such policies may result in the maldistribution of labor because unpaid volunteering can displace the paid work of low-skilled and low-paid employees (market world). Second, mandatory volunteering decreases their freedom of choice for a suitable activity with an appropriate intellectual level, and as such denies their status and previous achievements (world of fame). Third, the new policies have terminated remuneration practices, which were sometimes provided on top of benefit payments. This changes how they perceive the value of volunteering. Especially respondents with significant care tasks feel misrecognized by the requirement to volunteer without remuneration, because this is supposed to erode the fulfillment of their care priorities (domestic world). Finally, the obliged nature of volunteering conflicts with respondents' image of volunteering as a passion and a road to inspiration. This misrecognition of passion makes them feel forced in the wrong direction and hindered to find inspiring paid work (inspired world).

A popular objection to 'mandatory volunteering' is that, like other forms of third-party involvement (HaskiLeventhal et al. 2010; Hustinx and Meijs 2011), it violates the intrinsic freedom of volunteering. Our research broadens the playing field of both the academic and public discussion on 'workfare volunteering' by including the experiences of workfare volunteers themselves. For those to whom the measure applies, impairing the intrinsic freedom of volunteering is almost never the dominant issue. This of course does not make the issue irrelevant, on the contrary, but we do argue there are more perspectives to take into account.

Obligation, according to this research, has by no means such a decisive impact on the willingness to volunteer as many people expect and is claimed by a number of scholars (Clary et al. 1998; Levy 2006; Sobus 1995; Stukas et al. 1999; Warburton and Smith 2003). In fact, our research shows that the impact of obligation on the willingness is strongly related to the interpretative framework from which welfare clients assess the request to volunteer. We must consider the obligation in relation to this interpretative framework, since it helps us make sense of their interests, the conditions under which they wish to cooperate and the ways in which they want to be treated. In a 'world' in which volunteer work is also in the individual interest, because it enables, for example, something that is impossible in their current situation, welfare clients seem happy to cooperate and obligations are hardly an issue. However, in a 'world' in which volunteer work is purely in the public interest or contrary to their personal interest, welfare clients usually refuse to cooperate. In these cases, coercion even fills them with anger.

The interpretation of obligation is therefore only part of the decision to refuse or agree to volunteer. What someone hopes to find in volunteering is more decisive and 
determines the conditions under which someone is willing to cooperate. Welfare clients do not only formulate conditions because they object to something, but also because they expect to find something in volunteering. Most welfare clients have little against mandatory volunteering, as long as they have an interest in doing so. That idea is in line with the conditions formulated by neopaternalists like Goodin (1995) and Yeatman (2000).

The application of Boltanski and Thévenot's worlds of justification is also valuable for research into other thirdparty relations in volunteering. Application of their interpretative scheme may enrich academic debate by differentiating more systematically between justifications for or objections to third-party involvement, and may enable analysis of encounters at the intersection of the nonprofit sphere and other spheres, like the domestic and corporate sphere (e.g., Shachar et al. 2018).

Our theoretical contribution to the debate on redistribution and recognition is showing how 'othering' plays an important role in determining when mandatory volunteering becomes a matter of redistribution or recognition. A decisive factor in ideas regarding social justice was 'the other' that respondents had in mind. They do not only consider the impact on themselves, but also take in account the interest of rather abstract groups in society, like taxpayers, low-skilled or low-paid workers, and other welfare clients. Regarding redistribution, our study reveals strong differences between respondents. The other they have in mind seems to navigate them to widely varying judgments. While some see the policy as a fair redistribution of obligations and a way to give something back to taxpaying society for receiving 'free money,' others point out that voluntary 'free labor' is replacing low-paid labor, i.e., lowpaid employees losing their job and eventually ending up on welfare.

In terms of recognition, we also see widely differing opinions. Even despite the restrictions of freedom of choice, remuneration and personal development, already volunteering welfare recipients feel valued by the new policy. From a civic world perspective, obligation recognizes their contribution to the wider community and society. The policy also enables them to shake their fingers to others that are supposedly contributing less. This view echoes the work of Dworkin and Mead on behavioral requirements for earning respect. Even without any benefits in terms of income or career prospects, mandatory volunteering earned these respondents social justice by way of recognition. In contrast, other respondents perceive the obligation to give back something to society as misrecognition of their caring tasks, their passion, their capabilities, or their appearances.

When taking the judgments of workfare volunteers themselves into consideration, is mandatory volunteering a just policy? An important reason to answer this question negatively is that for most of them the only way to decline mandatory volunteering seems to be by claiming that their personal interests are being misrecognized or even harmed. Implementing this policy legitimates others to set these claims aside as signs of 'laziness' or 'a lack of work ethic' which can result in disarmament of people on welfare, and may further weaken their marginalized position in society. However, there is also a convincing reason to answer this question positively: mandatory volunteering recognizes that welfare clients are making or can make valuable social contributions outside the labor market. This of course only works for some; others experience it as misrecognition. An important precondition for mandatory volunteering to be experienced as recognition is that welfare clients' objections are listened to and taken seriously.

What does this mean for CSOs that employ workfare volunteers? How can they adequately manage workfare volunteers and their interests under the new policy regime? Our findings show how their volunteers judge the same policy measures in totally different ways. However, they all have their own particular reasons to volunteer: to provide for their children, to pay back to society, to follow their passion, or acquire status. They have in common that they need recognition for their reasons to volunteer. CSOs can recognize their reasons by listening to and respecting their preferences, considerations, and motivations. Obligation is inevitable under the new policy regime, but CSOs can still listen to volunteers' preferences and respect their 'freedom' of choice within boundaries set by the policy framework. Remuneration has ended, but CSOs can still consider the consequences for volunteers' appearances and the mouths they need to feed. Most importantly, CSOs can collectively raise concerns about policies that impact the lives of workfare volunteers. CSOs might be the linking pin between volunteers and government and therefore the designated advocate of workfare volunteers.

Finally, some issues for future research can be identified. Obviously, the external validity of this exploratory study is limited; follow-up research on a larger scale can provide more clarity on the variation of perceptions in the population of unemployed residents who are now participating in mandatory volunteering programs. Furthermore, there are indications that mostly older unemployed people with few chances on the labor market are primarily using the civic world perspective, while younger people prefer the inspired world narrative. The extent to which this difference is related to different labor market prospects deserves attention in future work. Further studies may also improve our insights in the effect of various socioeconomic characteristics (gender, education, and ethnic background) on various justifications of mandatory volunteering. Lastly, future research should focus on the perspective of CSOs on 
becoming sites of inclusion for welfare state activation policies. How do they perceive the fairness of workfare volunteerism in general and their own role in particular?

Funding This study was funded by Platform 31 (Grant Number KKS2-2012-02).

\section{Compliance with Ethical Standards}

Conflict of interest The authors declare that they have no conflict of interest.

Open Access This article is distributed under the terms of the Creative Commons Attribution 4.0 International License (http://crea tivecommons.org/licenses/by/4.0/), which permits unrestricted use, distribution, and reproduction in any medium, provided you give appropriate credit to the original author(s) and the source, provide a link to the Creative Commons license, and indicate if changes were made.

\section{References}

Balkenende IV, B. K. (2007). Samen werken samen leven. Den Haag. Boltanski, L., \& Thévenot, L. (2006). On justification: Economies of worth. Princeton: Princeton University Press.

Brady, M. (2011). Researching governmentalities through ethnography: The case of Australian welfare reforms and programs for single parents. Critical Policy Studies, 5(3), 264-282.

Clary, E. G., Snyder, M., Ridge, R. D., Copeland, J., Stukas, A. A., Haugen, J., et al. (1998). Understanding and assessing the motivations of volunteers: A functional approach. Journal of Personality and Social Psychology, 74(6), 1516.

Cnaan, R., Handy, F., \& Wadsworth, M. (1996). Defining who is volunteer: Conceptual and empirical considerations. Nonprofit and Voluntary Sector Quarterly, 25(3), 364-383.

Crang, M. (2002). Qualitative methods: The new orthodoxy? Progress in Human Geography, 26, 647-655.

de Jong, A. (2012). Tegenprestatie op maat biedt kansen. Adviesrapport Full Engagement. Rotterdam: DonaDaria.

De Waele, E., \& Hustinx, L. (2018). Governing through volunteering: The discursive field of government-initiated volunteering in the form of workfare volunteering. Nonprofit and Voluntary Sector Quarterly, 1-31. https://doi.org/10.1177/0899764018783094.

Dekker, P. (2002). On the prospects of volunteering in civil society. Voluntary Action, 4, 31-48.

Dworkin, R. (1981). What is equality? Part 1: Equality of resources. Philosophy and Public Affairs, 10, 185-246.

Fraser, N. (2000). Rethinking recognition: Overcoming displacement and reification in cultural politics. New Left Review, 3(May/ June), 107-120.

Fuller, S., Kershaw, P., \& Pulkingham, J. (2008). Constructing 'active citizenship': Single mothers, welfare, and the logics of voluntarism. Citizenship Studies, 12(2), 157-176.

Gilbert, N. (2004). Transformation of the Welfare State. The Silent Surrender of Public Responsibility. Oxford: Oxford University Press.

Goodin, R. (1995). In defense of the nanny state. In A. Etzioni (Ed.), Rights and the common good: A communitarian perspective. New York, NY: St Martin's Press.

Goodin, R. (2002). Structures of mutual obligation. Journal of Social Policy, 31(4), 579-596.
Hajer, M. (2006). Doing discourse analysis: Coalitions, practices, meaning. In M. van den Brink \& T. Metze (Eds.), Words matter in policy and planning-discourse theory and method in the social sciences (pp. 65-74). Utrecht: Nethur.

Handy, F., Cnaan, R. A., Brudney, J. L., Ascoli, U., Meijs, L. C., \& Ranade, S. (2000). Public perception of "who is a volunteer": An examination of the net-cost approach from a cross-cultural perspective. VOLUNTAS: International Journal of Voluntary and Nonprofit Organizations, 11(1), 45-65.

Haski-Leventhal, D., Meijs, L. C. P. M., \& Hustinx, L. (2010). The third party model: Enhancing volunteering through governments, corporations and educational institutes. Journal of Social Policy, 39(1), 139-158.

Hoggett, P., Wilkinson, H., \& Beedell, P. (2013). Fairness and the Politics of Resentment. Journal of Social Policy, 42(3), 567-585.

Hustinx, L., \& Meijs, L. C. P. M. (2011). Re-embedding volunteerism: In search of a new collective ground. Voluntary Sector Review, 2(1), 5-21.

Inspectie Sociale Zaken en Werkgelegenheid (2013). Voor wat hoort wat, Een beschrijving van de uitvoering van de tegenprestatie naar vermogen door gemeenten. September 2013. The Hague. http://www.inspectieszw.n1/Images/Voor-wat-hoort-wat_ tcm335-347217.pdf.

Kampen, T. (2014). Verplicht vrijwilligerswerk: De ervaringen van bijstandscliënten met een tegenprestatie voor hun uitkering. Amsterdam: Van Gennep.

Kampen, T., Elshout, J., \& Tonkens, E. (2013). The fragility of selfrespect: Emotional labour of workfare volunteering. Social Policy and Society, 12, 427-438.

King, D. (1995). Actively seeking work? The politics of unemployment and welfare policy in the United States and Great Britain. Chicago: University of Chicago Press.

Krinsky, J. (2008). Free labor: Workfare and the contested language of neoliberalism. Chicago: University of Chicago Press.

Levy, M. (2006). Volunteering for the dole: Good or bad? Australian Journal on Volunteering, 11(1), 38.

Lister, R. (2002). Towards a new welfare settlement? In C. Hay (Ed.), British politics today. Cambridge: Polity Press.

Mead, L. (1986). Beyond entitlement: The social obligations of citizenship. New York: The Free Press.

Mead, L. (1997). The new paternalism: Supervisory approaches to poverty. Washington, D.C: Brookings Institution Press.

Meijs, L. C. P. M., Handy, F., Cnaan, R. A., Brudney, J. L., Ascoli, U., Ranade, S., et al. (2003). All in the eyes of the beholder? Perceptions of volunteering across eight countries. In P. Dekker \& L. Halman (Eds.), The value of volunteering: Cross-cultural perspectives (pp. 19-34). New York: Kluwer/Plenum.

Moss, J. (2006). Mutual obligation and new deal: Illegitimate and unjustified? Ethical Theory and Moral Practice, 9, 87-104.

Muehlebach, A. (2012). The moral neoliberal: Welfare and citizenship in Italy. Chicago: University of Chicago Press.

Nevile, A., \& Warwick Nevile, J. (2003). Work for the dole: Obligation or opportunity. Sydney: University of New South Wales.

Newman, J., \& Tonkens, E. (2011). Participation, responsibility and choice: Summoning the active citizen in western European welfare states. Amsterdam: Amsterdam University Press.

Saunders, P. (2008). A whiff of compassion? The attack on mutual obligation. Issue Analysis, 96, 1-20.

Sawer, H. (2006). 'One Fundamental Value': Work for the Dole participants' views about work and mutual obligation. Paper presented to the Road to Where? Politics and Practice of Welfare to Work Conference, Brisbane, 17-18 July 2006.

Shachar, I. Y., Hustinx, L., Roza, L., \& Meijs, L. C. (2018). A new spirit across sectors: Constructing a common justification for 
corporate volunteering. European Journal of Cultural and Political Sociology, 5(1-2), 90-115.

Sobus, M. S. (1995). Mandating community service: Psychological implications of requiring prosocial behavior. Law and Psychology Review, 19, 153-182.

Soldatic, K., \& Meekosha, H. (2012). The place of disgust: Disability, class and gender in spaces of workfare. Societies, 2(3), 139-156.

Stukas, A., Snyder, M., \& Clary, E. (1999). The effects of 'mandatory volunteerism' on intentions to volunteer. Psychological Science, 10(1), 59-64.

Tilly, C. (2008). Why? What happens when people give reasons...and why. New Jersey: Princeton University Press.

Triantafillou, P. (2011). More of the same? The European employment strategy and the normalization of British employment policies. Critical Policy Studies, 5(1), 1-16.

Trommel, W., \& van de Berg, J. (2012). Echte wederkerigheid vernedert niet. Sociale Vraagstukken, April 15. www.socialev raagstukken.nl/site/2012/04/15/echte-wederkerigheid-vernedertniet/. Accessed 7 October 2014.

van der Veen, R., Achterberg, P., \& Raven, J. (2012). Contested Solidarity. In R. van der Veen, M. Yerkes, \& P. Achterberg (Eds.), The transformation of solidarity (pp. 31-48). Amsterdam: Amsterdam University Press.

Veldheer, V., Jonker, J., Noije, L. van, \& Vrooman, C. (2012). Een beroep op de burger. Minder verzorgingsstaat, meer eigen verantwoordelijkheid? Sociaal en Cultureel Rapport 2012. The Hague: Sociaal en Cultureel Planbureau.

Verhoeven, I., \& Tonkens, E. (2013). Talking active citizenship: Framing welfare state reform in England and The Netherlands. Social Policy and Society, 12(3), 415-426.

Volkskrant, D. (2012). 'We gaan in Rotterdam van een uitkeringsnaar een werkfabriek' (Interview with alderman Florijn). November 30, 2012.

Warburton, J., \& McDonald, C. (2002). Compulsory volunteering' under mutual obligation policies: Implications for the future. Just Policy, 26, 11-17.

Warburton, J., \& Smith, J. (2003). Out of the generosity of your heart: Are we creating active citizens through compulsory volunteer programmes for young people in Australia? Social Policy and Administration, 37(7), 772-786.

Wolff, J. (2008). Social justice and public policy: A view from political philosophy. In G. Craig, T. Burchardt, \& D. Gordon (Eds.), Social Justice and public policy: Seeking fairness in diverse societies (pp. 17-31). Bristol: The Policy Press.

Yeatman, A. (2000). Mutual obligation: What kind of contract is this? In S. Shaver \& P. Saunders (Eds.), Reforming the Australian welfare state. Melbourne: Australian Institute of Family Studies.

Publisher's Note Springer Nature remains neutral with regard to jurisdictional claims in published maps and institutional affiliations. 